\title{
ISLAMIC MARKET MECHANISM ACCORDING TO ABU YUSUF AND HIS WILLINGNESS TO THE PANORAMA MARKET MECHANISM OF KOTA BENGKULU
}

\author{
Idwal $B^{1} \&$ Sahara Ratna Sari ${ }^{2}$ \\ 1, 2 Fakultas Ekonomi dan Bisnis Islam IAIN Bengkulu, \\ Jl. Raden Fatah Pagar Dewa Bengkulu \\ Email: ${ }^{1}$ idwalkincai@gmail.com; ${ }^{2}$ Sahararatnasari@gmail.com
}

\begin{abstract}
The Islamic Market Mechanism According to Abu Yusuf and its Relevance to the Panorama Market in Bengkulu City, the research method used in this study is library research, the research approach, and data collection techniques used are qualitative data (qualitative research) and documentation. The analysis technique used is inductive deductive, and descriptive. Based on the specific fission and style that applies to the character, the inductive method is better understood than general conclusions are drawn. The deductive method is collecting, analyzing, and researching general data to draw specific conclusions. The descriptive method is the regular description of all conceptions of the characters regarding the topic or research discussion. From the results of this study, it was found that the market and price mechanism according to Abu Yusuf is a practice that provides general problems (al-mashlahah al'-ammah), both from the producer (seller) and the buyer, while the relevance of the Islamic Market mechanism at the Panorama Market in Bengkulu City irrelevant and can not be fully implemented as the Islamic market mechanism according to the thought of Abu Yusuf.
\end{abstract}

Keywords: Abu Yusuf; Islamic Market Mechanism; Panorama Market

\begin{abstract}
Abstrak: Dalam ekonomi Islam, harga wajar dan adil (fair price) merupakan suatu harga yang diperoleh berdasarkan kekuatan penawaran (supply) dan permintaan (demand). Hubungan antara pasar, pemerintah dan individu adalah sejajar. Fokus penelitian ini adalah bagaimana relevansi mekanisme pasar Panorama terhadap mekanisme pasar islami menurut Abu Yusuf. Metode penelitian yang digunakan adalah penelitian kepustakaan (library research). Pengumpulan data yang digunakan adalah data kualitatif dan dokumentasi. Teknik analisanya adalah induktif deduktif dan deskriptif. Dari hasil penelitian ini diperoleh bahwa mekanisme pasar dan harga menurut Abu Yusuf adalah suatu praktik yang memberikan kemaslahatan umum (al-mashlahah al'-ammah), baik itu dari pihak perodusen (penjual) maupun pembeli. Sedangkan relevansi mekanisme pasar Islami pada pasar Panorama kota Bengkulu, tampak tidak relevan dan belum dapat dijalankan sepenuhnya sebagaimana mekanisme pasar Islami menurut pemikiran Abu Yusuf.
\end{abstract}

Kata kunci: Abu Yusuf; Mekanisme Pasar Islami; Pasar Panorama 


\section{Introduction}

To meet human needs, they cannot be separated from buying and selling activities because humans do buy and sell activities almost every day. This buying and selling activity will create an agreement between the seller and the buyer called the price. Price is a value that the buyer must spend to get goods or services that have proper value and service, flexible prices, and can be adjusted. Before pricing, one must know the purpose of the pricing itself. If the goal is clear, then pricing can be done quickly. A fair price is a price that does not cause exploitation or oppression (tyranny) so that it can harm one party to the other. The price should reflect the benefits to both the buyer and seller somewhat. The fair price is when the seller earns an average profit and the buyer gets the benefit that matches his price. The existence of a fair price becomes a fundamental guideline in Islamic transactions. Pricing in the market depends on sufficient demand and supply. ${ }^{1}$

In Islamic economics, fair and fair price is a price obtained based on supply (supply) and demand (demand)-the parallel relationship between markets, governments, and individuals. However, the reality on the ground, the fair market, and the absence of tyranny often do not happen. Therefore, Islam asserts that market mechanisms and pricing need to be regulated to uphold market balance and economic justice, taking into account the interests of the parties involved in the market. ${ }^{2}$

The Qur'an, as a guide to life, explains the thing in finding treasure in His pleasure as it is explained in Q.S. Al-Hadid [57]: 25, this verse places justice as the most crucial

\footnotetext{
${ }^{1}$ Buchari Alma dan Dooni Juni, Manajemen Bisnis sayariah, (Bandung: ALFABETA, 2014), p. 142.

${ }^{2}$ Lukman, Hakim. "Distorsi Pasar Dalam Pandangan Ekonomi Islam”, Ekomadania: (2017) Vol,01(1), p.15.
}

element in sharia maqashid. Sayyid Qutb says that justice is:

"as a comprehensive and most important element in all aspects of life. If the meaning of justice has worked as it should, then people's lives will be prospered."3

In line with Islamic economic thought, according to Abu Yusuf that in carrying out economic activities, there must be a general problem (al-mashlahah al-'-ammah) based on the Qur'an and Sunnah so that finally the benefit can be realized. Measure in achieving public benefit according to Abu Yusuf, with several aspects such as balance (tawazun), free will (al-ikhtiar), responsibility/justice (al-'is), and doing good (al-ihsan). According to Abu Yusuf, the market is:

"The system follows and provides optimal freedom for the actors in it, namely producers and consumers but in the event of activities such as monopolies, hoarding, other corrupt actions or unnatural unilateral actions of producers then efforts to achieve and provide general problems (al-mashlahah al'-ammah) in the market cannot be carried out properly." ${ }^{4}$

Abu Yusuf's version of the Islamic market mechanism is a path that must always prioritize the attitude of benefit for the actors, namely sellers (producers) and buyers. However, suppose there is one party who feels injustice or ugliness due to such mechanisms or interactions. In that case, according to Abu Yusuf, the practice of benefit cannot be carried out and realized as it should be. The author found the gap between the Thinking of Abu Yusuf about Islamic market mechanisms and the mechanisms that occur in the Panorama

\footnotetext{
${ }^{3}$ Pusat Pengkajian dan Penembangan Ekonomi Islam (P3EI), Ekonomi Islam, (Jakarta: Rajawali perss, 2009), p. 59

${ }^{4}$ Nurul huda dan Ahmad Muti, Kuangan Publik Isalam pendekatan Al-Kharaj Imam Abu Yusuf, ( Bogor: Gahlia Indonesia, 2011) p. 62.
} 
market of Bengkulu city. The gap the author got in Emelda Ernawati's article entitled "Potential of Rice Traders In Increasing Revenue Reviewed from The Perspective of Islamic Business Ethics (Traditional Market Case Study Of Bengkulu City Panorama Pilot)." In this article, there is a problem that the rice swords contained in the Panorama market increase their opinions. Many traders do naughty practices by mixing old rice and good rice into one, and with this activity, they will be able to maximize their profits or income. Conversely, consumers will feel the benefits that are not good with fraudulent activities or practices. ${ }^{5}$

In the above writing, it is evident that there are fraudulent actions of some rice traders that can cause harm to consumers, and with the action of reducing scales and mixing rice is very contrary to the thinking of Abu Yusuf, because according to him, the benefit is the main form in a suitable market mechanism. This proves that many frauds or unfair actions are contained in the transaction activities of buying and selling rice in the Panorama Market of Bengkulu City. However, it must be noted that not all traders commit the practice of cheating the reduction.

\section{Islamic Market Mechanism}

The market mechanism is the interaction between demand and supply that will determine a specific price level. The transaction will increase the process of transferring goods and services owned by each economic object.

The market mechanism is indeed not separated from the factor of production because where there are comments there must

\footnotetext{
5 Imelda Hernawati, Potensi Pedegang Beras dalam meningkatkan Pendapatan di Tinjau dari PerspektifEkonomi Islam (Studi kasus pada Pasar Percontohan Panorama Kota Bengkulu), (Tesis: IAIN Bengkulu, 2019) p. 74.
}

be producers. These verses on production have been hinted at by Allah SWT in the Qur'an as follows:

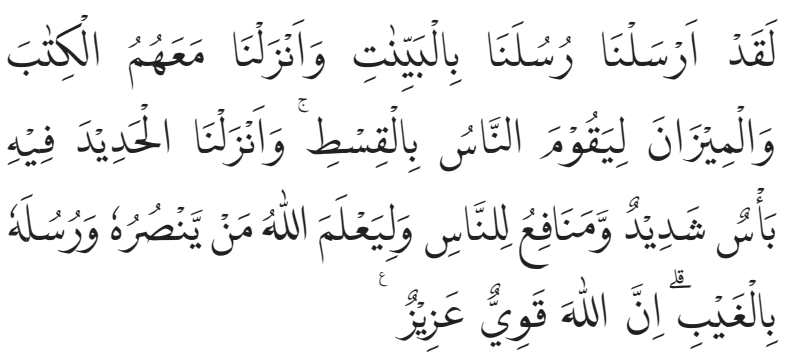

"We have sent Our Messengers with clear evidence, and We have sent down with them the book and the balance of justice so that people may do justice. Moreover, We created an iron in which there is great strength and benefit to humankind, and that Allah may know who helped him and his messengers, but Allah did not see him. Indeed God is strong again. (Q.S Al-Hadid [57]: 25).

In verse, it is clear that it has issued a balance sheet (justice) to humans in the system of market mechanisms, wherein carrying out a particular transaction must be based on the court, namely between producers and consumers. In addition, the Prophet said:

"Two people who do buy and selling have the right to vote while they have not separated from each other until both are honest and explanation, then both are blessed in the sale and purchase, but if both hide and lie then the blessing of buying and selling is abolished." (H.R. Bukhari Muslim).

It is explained that there must be no mutual lying between sellers and buyers but openness in making a transaction. Islam cares deeply about the economy. So the market mechanism is determined by consumer demand that wants something. These producers provide goods, coupled with the government that controls the market mechanism system in terms of the regulation (applied explicitly in Indonesia). Some of the thoughts of market mechanisms according to Islamic economic thinkers include the following: 


\section{Ibnu Taimiyah (661-728)}

Contained in the book of Al-Hisbah, Ibn Taymiyyah has spoken of market mechanisms through the concept of price theory and the power of supply and demand in his works.

When people assumed that the price increase was the result of injustice and unlawful acts of the seller or believed as a result of market manipulation, Ibn Taymiyah immediately denied it. He firmly said that the strength of supply and demand determines prices.

In his broader view, Ibn Taymiyyah further proposed the concept of market mechanisms in his book "Al-Hisbah fi al-Islam." He said that in a healthy market, prices are influenced and considered by the forces of supply and demand. Goodwill falls in price if there is an abundance in production or a decrease in imports of needed goods. Instead, he reveals that a price can rise because of a "decrease in the number of available goods" or an "increase in the number of people," indicating an increase in demand. Ibn Taymiyyah said that the arbitrary actions of the seller did not always cause the rise and fall of prices. It could be that the cause is due to declining supply due to production inefficiencies, a decrease in the number of imports of goods requested, or also market pressures. ${ }^{6}$

Therefore, if the demand for goods increases while supply decreases, then the price of goods will rise. Vice versa, if demand decreases while supply increases, then prices will fall. (Scarcity or abundance of goods may be due to appropriate actions and may also be caused by the actions of certain people unjustly or unjustly. ${ }^{7}$

\footnotetext{
${ }^{6}$ Adiwarman A.Karim, Ekonomi Mikro Islam...., p. 257

${ }^{7}$ Adiwarman A.Karim, Ekonomi Mikro Islam..., p. 258
}

\section{Abu Yusuf (731-798)}

According to Abu Yusuf, the Islamic economic system follows the market mechanism by providing optimal freedom for the actors, namely producers and consumers. However, monopolies, hoarding, other corrupt actions, or unnatural unilateral actions of producers, efforts to achieve and provide general problems (al-mashlahah al'-ammah) in the market cannot be realized. ${ }^{8}$

Abu Yusuf made maslahah the basic framework in making policy. He revealed when advising Caliph Harun ar-Rashid the following:

"And do what you think is most important to Muslims and most beneficial to minorities and majorities paying to save or maintain religion for your good.."

Maslahah al-' ammabIt is a public affair that concerns the interests of the establishment of religious affairs and the world, including preventing the destitution of the people (Muslims) and establishing social control through amar máruf nahi munkar. Allah (SWT) says in the Qur'an about maslahah or goodness, namely in the letter of Al-'Araf verse 56 as follows:

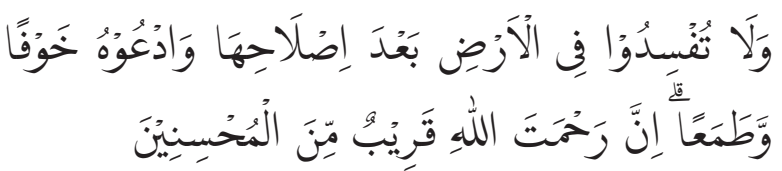

"And do not do any damage on the earth, after (Allah) has repaired it and prayed to Him with fear (will not be received) and hope (will be granted). God's mercy is close to those who do good. (Q.S Al-'Arraf [7]: 56).

The word ishlahiha contained in the above verse also refers to the meaning of goodness or good. This is evident from the prohibition

\footnotetext{
8 Nurul huda dan Ahmad Muti, Kuangan Publik Isalam pendekatan Al-Kharaj Imam Abu Yusuf..., h. 65 -70

${ }^{9}$ Abu Yusuf, Al-Kharaj, Beirut: Darul Ma’rifat, 1979
} 
affirmed by Allah SWT to the people not to do anything that damages the earth's surface. For Allah has created an excellent condition conducive to the survival of living things on the earth's surface. Nevertheless, it is the irresponsible hands of man himself that then damage his environment. Thus It causes an imbalance in the ecosystem that leads to various forms of natural disasters.

Allah will not command his servants to do anything but for the good of his servants. So it is with prohibition, for Allah will not hold His servants from an act or not but for their goods. So any action done by humans that leads to damage is contrary to the purpose desired by Allah Swt. Therefore, such actions are called facades (destruction) that cause mafsadah (damage). ${ }^{10}$

Abu Yusuf wanted to say that in reality, prices depend not only on the power of supply but also on-demand. Therefore an increase or decrease in price is not necessarily associated with a decrease or increase in production. $\mathrm{He}$ explicitly said several other variables affected, but he did not explain in detail. Nevertheless, it could be that the variable is a shift in the demand or the amount of money in circulation in a country, or the hoarding and holding of goods, or all of those things. According to Siddiqi, as quoted by Adiwarman, Abu Yusuf's remarks should be accepted as a statement from observations at the time, namely the simultaneous existence between the abundance of goods and the high price and scarcity of goods low prices.

It is essential to know that the rulers of that period generally solved price increases by adding food supply and avoided price controls. The tendency in economic thought is to rid the market of hoarding practices, monopolies,

${ }_{10}$ Zul Iklromi, Maslahah dalam Al-Qur'an ( sebuah pengantar), An-Nur, Vol, 4 No.( 2), 2015 and other corruption and then allow pricing to the forces of demand and supply.

While the economic system desired by Abu Yusuf is an effort to achieve and provide general problems (al-mashlahah al-'ammah). This benefit is based on the Qur'an, Hadith, and other foundations. The measure of maslahah, according to Abu Yusuf can be measured from several aspects, namely balance (tawazun), free will (al-ikhtiar), responsibility or justice (al-'is), and doing good (al-ihsan). ${ }^{11}$

\section{Al-Ghazali (1058-1111)}

For the context of his time, Al-Ghazali's thoughts on the law of supply and demand are pretty advanced and surprising, and he seems to understand the concept of elasticity of demand. "Reducing profit margins by selling at lower prices will increase sales volume, and this, in turn, will increase profits. He has also identified food products as commodities with an inelastic demand curve. He commented, "since food is a staple, the food trade should be minimally encouraged not to be solely in the search for profit. The business of staple foods should be avoided exploitation through the imposition of high prices and large profits. This kind of profit should be sought from items that are not necessities. Imam Al-Ghazali, like other Muslim scholars in talking about price, has always associated it with profit. He has not linked the price of goods to income and costs. ${ }^{12}$

For Al-Ghazali, profit (ribh) compensation for travel difficulties, business risks, and safety threats to the trader. Although AlGhazali mentions profit in his writings, it is

11 Nurul huda dan Ahmad Muti, Kuangan Publik Isalam pendekatan Al-Kharaj Imam Abu Yusuf..., p. 65.

12 Adiwarman Azwar Karim, Sejarah Pemikiran Ekonomi Islam, (Depok: PT RajaGrafindo Persada, 2007), p. 260 
understandable that what he meant was the price. That is, prices can be influenced by travel security, risk, and many more. Safe travel will encourage the influx of imported goods and lead to an increase in supply, resulting in prices falling. And vice versa. This study should add a little thought al-Ghazali about the concept of profit in Islam. According to him, the motive of trading is to make a profit. However, he disagreed with the significant advantages of trading motives, as capitalism teaches.

According to $\mathrm{Al}$-Ghazali, the advantage in trading is that the business profit that a trader wants to achieve is the profit of the afterlife, not the profit of the world alone. What is meant by the profit of the afterlife seems to be first, the price pegged by the seller should not double from the capital, thus burdening consumers. Second, trading cannot be separated from the part of the realization of ta'awun (please help) that Islam recommends. Merchants make a profit while consumers get the needs they need. Third, trading according to Islamic economic ethics is the application of shari'ah, so it is considered worship.

\section{Ibnu Khaldun (1332-1404)}

In the book of Al-Muqaddimah, he explicitly wrote a chapter entitled "Prices in the City." He divided the types of things into two kinds. First, basic goods; Second, luxury goods. According to him, if a city develops and its population increases, then the procurement of essential goods gets priority so that the supply increases and, consequently, prices fall. As for luxury goods, the demand will increase, in line with the city's development and lifestyle changes. As a result, the price of luxury goods went up. Next, he explained the effect of the rise and fall of the offer on the price. According to him, when the goods are available a little, then the prices will go up. However, suppose the distance between the city is close and amam. In that case, there will be many goods imported. The availability of goods will be abundant, and prices will decrease. The exposure shows that Ibn Khaldun as Ibn Taymiyah has identified the strength of demand and supply as determinants of price balance. Still related to the theory of supply and demand, Ibn Khaldun explained in more detail. He believes reasonable profits will encourage trading growth, while meager profits will make the trade sluggish because traders lose motivation. Conversely, if traders take very high profits, the trade will also be sluggish because of weak consumer demand. ${ }^{13}$

Compared to Ibn Taymiyah who did not use the term competition, Ibn Khaldun explicitly explained the elements of competition. He also explicitly explained the types of costs that make up the supply curve, while Ibn Taymiyah explained them implicitly only. ${ }^{14}$

\section{Biography of Abu Yusuf}

In Islamic literature, Abu Yusuf is often referred to as Imam Abu Yusuf Ya'qub bin Ibrahim bin Habib al-Ansâri al-Jalbi al-Kufi al-Baghdâdi, was born in $113 \mathrm{H} / 731 / 732 \mathrm{AD}$ in Kufa and had lived in Baghdad, and died in $182 \mathrm{H} / 798 \mathrm{AD}$. He came from the tribe of Bujailah, one of the Arab tribes. His family is called Anshori because from the mother's side still has a relationship with the Anshor (the first Muslim and helper of the Prophet Muhammad) during his life in Kufa, which is famous as an area of education inherited by Abdullah Ibn Mas'ud (w. $32 \mathrm{H}$ ) a great friend of the Prophet Muhammad (peace be upon him). ${ }^{15}$

\footnotetext{
${ }^{13}$ Adiwarman A.Karim, Ekonomi Mikro Islam.., p. 330

${ }^{14}$ Adiwarman A.Karim, Ekonomi Mikro Islam.., p. 332

${ }^{15}$ Nurul Huda dan Ahmad Muti, Keuangan Publik..., p. 55
} 
Abu Yusuf, in the history of his life, was not born to a wealthy family. He was born to a low-income family in a small village in Baghdad, Iraq. As a child, he had to work with his parents. His father told him to work as a dresser who had been shabby to look neat, but his love for knowledge made him absent to take a break. Several times Abu Yusuf's father had to drag him out of the mosque to keep working because their families had many children and relatives who needed something to eat. However, Abu Yusuf remained with his founder, who went to the mosque following the lessons learned by Abu Hanifah. ${ }^{16}$

Abu Yusuf studied to many great scholars, such as Abu Muhammad Atha bin As-Saib AlKufi, Suliman bin Mahran Al-A' masy, Hisham bin Urwah, Muhammad bin Abdurahman bin Abi Laila, Muhammad bin Ishaq bin Yassar bin Jabbar, and Al-Hajjaj bin Arthah and also Abu Hanifa, but because of the economic problems of Abu Yusuf did not have time to come to study to make a living, Abu Yusuf studied until the teacher Abu Hanifah died. ${ }^{17}$

In his education, Abu Yusuf became a disciple of Abu Hanifah for 17 years and several prominent scholars at that time. Seeing the talent and passion, and perseverance of Abu Yusuf in learning, Imam Abu Hanifah was willing to finance all his educational needs, even the cost of living for his family. Imam Abu Hanifa was hopeful that Abu Yusuf would continue and spread the Hanafi school in various directions. This can be understood from Abu Hanifa's expression that Abu Yusuf was a mighty man of memorization and knowledge. No one in the whole world is more knowledgeable than Abu Joseph. The expression gives the idea that if Abu Hanifah

\footnotetext{
${ }^{16}$ Nurul Huda dan Ahmad Muti, Keuangan Publik..., p. 54

17 Hendi Suhendi, Peradaban Pemikiran Ekonomi Islam, (Bandung: Pustaka Stia, 2010), p. 151
}

had no disciples other than Abu Yusuf, he would have been enough to be a significant pride for humankind. ${ }^{18}$

\section{Islamic Market Mechanism (Price) According to Abu Yusuf}

Abu Yusuf was the first cleric to begin to allude to market mechanisms related to prices in the market. It notices the increase and decrease in production concerning price changes. In contrast to the understanding that is angry when few goods are available, the price will be high and vice versa. Abu Yusuf stated, there are no particular limits on cheap and expensive that can be ascertained. It is something that regulates it. The principle is unknown. Cheap not because of the abundance of food, nor is it expensive not due to food scarcity. Cheap and expensive is God's will. Abu Yusuf stated:

"Sometimes food is plentiful, but it remains expensive and sometimes very little but cheap food." 19

Abu Yusuf wanted to say that in reality, prices depend not only on the power of supply but also on-demand. Therefore an increase or decrease in price is not necessarily associated with a decrease or increase in production. $\mathrm{He}$ explicitly said several other variables affected, but he did not explain in detail. However, the variable is a shift in demand or the amount of money in circulation in a country, the hoarding and holding of goods, or all of those things. ${ }^{20}$

A market is a place or place that brings together a demand (buyer) or supply (seller) for any goods, service or resource. Market

${ }^{18}$ Majid, M. Nazori, Pemikiran Ekonomi Islam Abu Yusuf, Cet. I, (Yogyakarta: PSEI STIS, 2003), p. 122

19 Boedi Abdullah, Peradaban Pemikiran Ekonomi Islam, (Bandung: Pustaka Setia,2002), p.163

20 Adiwarman, A.Karim, Ekonomi Mikro Islam, (Depok: Rajawali Pers, 2017), p.208 
mechanisms (price) are the interaction between demand and supply to determine a certain price level. According to Yusuf, the market mechanism is the market mechanism by providing optimal freedom for the actors in it, namely producers and consumers but if there are activities such as monopolies, hoarding, other corrupt actions or unnatural unilateral actions of producers then efforts to achieve and provide general problems (almashlahah al-'ammah) in the market cannot be realized. ${ }^{21}$

The economic system desired by Abu Yusuf was an attempt to achieve and provide general problems (al-mashlahah al'-ammah). This benefit is based on the Qur'an, al-Hadith, and other foundations. The measure of maslahah, according to Abu Yusuf can be measured from several aspects, namely balance (tawazun), free will (al-ikhtiar), answer/justice (al-'is), and do good (al-ikhasn). ${ }^{22}$

Maslahah etymologically means something good, tasted delicious, therefore causes pleasure, satisfaction and is accepted by common sense. The tremendous Indonesian dictionary interprets maslahah as something that brings good. Abu Yusuf made maslahah the basic framework in making policy. This he expressed when advising Caliph Harun arRashid:

"And do what you think is most beneficial to Muslims and most beneficial to minorities and the majority, most saving or maintaining religion for your good."23

Maslahah al-'ammah is a public affair that concerns the interests of the establishment of religious and world affairs, including preventing the destitution of the people (Muslims) and

${ }^{21}$ Nurul huda dan Ahmad Muti, Kuangan Publik Isalam pendekatan Al-Kharaj Imam Abu Yusuf..., p. 62

22 Nurul huda dan Ahmad Muti, Kuangan Publik Isalam pendekatan Al-Kharaj Imam Abu Yusuf..., p. 63

${ }^{23}$ Abu Yusuf, Al-Kharaj, Beirut: Darul Ma'rifat, 1979 establishing social control through amar ma'ruf nahi munkar. Allah says in the Qur'an about maslahah or goodness, that is, in surah Al-'Araf verse 56 as follows:

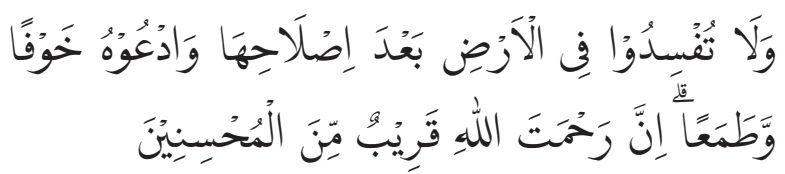

"And do not do any damage on the earth, after (Allah) has repaired it and prayed to Him with fear (will not be received) and hope (will be granted). God's mercy is close to those who do good. (Q.S Al-Arraf: 56)

The word ishlahiha contained in the above verse also contributes to the meaning of goodness or good. This is evident from the prohibition affirmed by Allah SWT to the people not to do anything that damages the earth's surface. For Allah has created an excellent condition conducive to the survival of living beings on the earth's surface. However, it is the irresponsible hands of man himself who can then damage his environment. Thus it causes an imbalance in the ecosystem that leads to various forms of natural disasters.

Allah will not give his servants to do anything but for the good of his servants. So is the prohibition because Allah (SWT) will not hold His servants from an act or not but for their excellence. So any action done by man that leads to damage is contrary to the purpose that Allah SWT has wanted. Therefore such actions are called facades (destruction) that can cause mafsadah (damage). ${ }^{24}$

It can be concluded that according to Abu Yusuf, the Islamic market mechanism (price) is a path that gives complete freedom to the actors in it, namely producers and consumers. However, if there are activities such as monopoly, hoarding, riba, other

${ }_{24}$ Zul Iklromi, Maslahah dalam Al-Qur'an ( sebuah pengantar), An-Nur, Vol, 4 No.( 2), 2015 
corrupt actions, or unnatural unilateral actions of producers, then efforts to achieve and provide general problems (al-mashlahah al'-ammah) in the market cannot be realized and carried out.

According to the author's analysis that the Islamic market mechanism (price) according to Abu Yusuf is an activity carried out by both sellers and buyers in the market, by carrying out sales and purchase practices in which there must be principles of responsibility or fairness and doing good, causing good or positive benefits (maslahah) that actors in the market can feel. No one feels aggrieved by the activities of the mechanism market. Alternatively, in other words, allow all activities contained in the market, as long as it does not violate the use of an unlawful provision. Economic activity must be based on how the norms are in the provisions of Islamic economic shariah.

\section{Abu Yusuf's Islamic Market Mechanism and Its Relevance to the Panorama Market Mechanism}

In economic activity, the market links producers and consumers as a connecting medium to bring together sellers and buyers between the business world and the consumer community. Similarly, in the modern economy, the market plays a crucial game because prices are formed in the market, and with the help of prices in the market, the subject of economic problems is what, how, and for whom can be solved. ${ }^{25}$

The market is a mechanism that can bring together sellers and buyers to make transactions on goods and services, both in the form of production and pricing. The primary condition of the market formation is a meeting between the seller and the buyer,

25 T. Gilarso, Pengantar Ilmu Ekonomi Bagian Makro, (Yogyakarta: Kanisus, 1994), Cet. Ke-2, p. 154. either in a place or in a different place. In the capitalist system, the market has a significant role in moving the wheels of economic life. ${ }^{26}$

While the economic system desired by $\mathrm{Abu}$ Yusuf is an effort to achieve and provide general problems (al-mashlahah al-'ammah). This benefit is based on the Qur'an, Hadith, and other foundations. The measure of maslahah according to Abu Yusuf can be measured from several aspects, namely balance (tawazun), free will (al-ikhtiar), answer or justice (al-'is) and do good (al-ihsan). ${ }^{27}$

\section{1) Balance (tawazun)}

Balance or 'adl (justice) describes the horizontal dimension of Islamic teachings and the relationship to the harmony of everything in the universe. The laws and order seen in the universe reflect a harmonious balance. This order is also known as sunnatullah. In the world of work and business, Islam requires to do justice, not least to those who are not liked. Islam requires its adherents to be and do good.

Moreover, even fairness must take precedence over good. The most basic fair requirement in business is for Muslim entrepreneurs to perfect the measure when measuring and weighing with the correct scales. It is the best behavior that will bring fear closer to piety. ${ }^{28}$

\section{2) Free will (al-ikhtiar)}

On some level, man is given free will to control his own life when Allah (SWT) lowers

${ }^{26}$ Said Sa'ad Marthon, Ekonomi Islam Ditengah Krisis Global, Terjemahan Ahmad Ikhrom, (Jakarta: Zikrum Hakim, 2004), Cet. Ke-1, p. 76.

${ }^{27}$ Nurul huda dan Ahmad Muti, Kuangan Publik Isalam pendekatan Al-Kharaj Imam Abu Yusuf...., p. 65

${ }^{28}$ Rafik Issa Beekun, Etika Bisnis Islami, (Yogyakarta: Pustaka Pelajar, 2004), p. 33 
it to earth. By ignoring the fact that the way of life is desired and, most importantly, acting on the rules he chooses. The Islamic concept understands that economic institutions such as markets can also play an influential role in economic life.Manusia memiliki kecenderungan untuk berkompetisi dalam segala hal, tak terkecuali kebebasan contract in the market. Therefore, the market should reflect the law of supply and demand represented by price; the market is not distorted by hands that deliberately play it. Islam does not give room for intervention from any party to determine the price unless there is an emergency. ${ }^{29}$

\section{3) Responsibility or justice (al-'adalah)}

Unlimited freedom is impossible for people to do because they do not demand accountability. To meet the demands of justice and unity, man needs to be held accountable for his actions. Logically, this principle is closely related to the principle of free will. He sets limits on what man is free to do by taking responsibility for everything he does. ${ }^{30}$

\section{4) Doing good (al-Ihsan).}

Ihsan (virtue) means doing good deeds that can benefit others, without certain obligations that require such acts, or in other words, worship and do good as if they see God; if not able, then be sure God sees. A market mechanism, according to Abu Yusuf, is an Islamic economic system following the market mechanism by providing optimal freedom for the actors in it, namely producers and consumers, but if there are activities such as monopolies, hoarding, other corrupt actions, or unnatural unilateral actions from producers, then efforts to achieve and provide

\footnotetext{
${ }^{29}$ Rafik Issa Beekun, Etika Bisnis Islami..., p. 33

${ }^{30}$ Rafik Issa Beekun, Etika Bisnis Islami..., p. 34
}

general problems (al-mashlahah al-'ammah) in the market cannot be realized. ${ }^{31}$

In line with Abu Yusuf's thoughts about the mechanism, the market is in doing the activities of peace is there must be benefits (good benefits). The benefit in question is the benefit that is based on the Qur'an, Hadith, and maqasid shari'ah. In fixing the economic mechanism, Abu Yusuf said there must be a way to divide between rich and poor so that every actor in the market can feel the benefits and sound in a healthy market mechanism. While, according to the observation of Abu Yusuf, there are still many sellers or producers who in conducting trading activities (muamalah) still carry out buying and selling activities that can hinder the entry of benefits in the market.

So it can be concluded that according to $\mathrm{Abu}$ Yusuf as described above, the Islamic market always concerns the attitude of maslahah in carrying out the market mechanism (price). Because for him, the benefit is the leading benchmark in carrying out something including buying and selling activities, which must be following the guidelines in peace that is based on the Qur'an and hadith and other sources. For the relevance of Islamic market mechanisms (prices) that occur in the Bengkulu City Panorama Market, it seems irrelevant because there are still some traders or producers who commit fraudulent actions in the form of scale reduction other things that can cause harm to consumers. The practice that occurs in the market mechanism (price) in the Bengkulu City Panorama Market is not yet practicable and entirely run because some people still do not have the awareness that in carrying out muamalah practice activities must be following the teachings and norms in Islamic shariah. Such as providing good

\footnotetext{
31 Nurul huda dan Ahmad Muti, Kuangan Publik Isalam pendekatan Al-Kharaj Imam Abu Yusuf..., p. 65 -70
} 
reciprocal benefits among the transacting parties and ensuring the common welfare of producers, sellers, and buyers.

\section{Conclusion}

Based on the results of the previously outlined research, it can be concluded as follows:

1. Mekanime market, according to Abu Yusuf, is an attempt to achieve and give general problems (al-mashlahah al-'ammah). This benefit is based on the Qur'an, Hadith, and other foundations. According to him, the market mechanism (price) must provide optimal freedom for the actors, namely producers (sellers) and consumers. However, if there are activities such as monopoly, hoarding, usury, other corrupt actions, or unnatural unilateral actions of producers, then efforts to achieve and provide general problems (al-mashlahah al'ammah) in the market cannot be realized.

2. According to Abu Yusuf, the market mechanism that occurs in Panorama Market is not relevant to the Mechanism of the Islamic Market because, in reality. There are still many traders or producers who commit fraudulent acts, scale reduction, and other injustices that can cause harm to consumers.

\section{References}

Abdullah, Boedi, Peradaban Pemikiran Ekonomi Islam, Bandung: Pustaka Setia, 2010.

Agustianto, Mekanisme Pasar Dalam Perspektif Ekonomi Islam, dikutip dari http://www. agustiantocentre.com/? $\mathrm{p}=1534$, pada selasa, tanggal 22 Agustus 2020, pukul 10:00 wib.

Andiko, Toha. "Signifikansi Implementasi Konsep Ekonomi Islam dalam Transaksi Bisnis di Era Modern", Jurnal Ilmiah Mizani, Vol. 4, No. 1 (2017).

Andiko, Toha. "Konsep Harta dan pengelolaannya dalam Alquran”, Al-Intaj, Vol. 2, No. 1 (2016).
Arikunto, Suharsami. Prosedur Penelitian Suatu Pendekatan Praktek, Jakarta: Mulya Rineka Cipta, 2006.

Alma, Buchari dan Doni Juni. Manajemen Bisnis sayariah, Bandung: ALFABETA, 2014.

Beekun, Rafik Issa. Etika Bisnis Islami, Yogyakarta: Pustaka Pelajar, 2004.

Condro, Triono Dwi. Ekonomi Islam Madzhab Hamfara, Falsafah Ekonomi Islam Jilid I, Bantul: Irtikaz, 2011, Cet. II

Djam'an, Santori. dan Aan Komariah. Metodologi Penelitian Kulitatif, Bandung: Alfabeta, 2017.

Departemen Agama RI, Al-Qur'an perjemahnya, Bandung: PT Sygma Examedia Arkanlemma, 2016.

Fatoni, Siti Nur, Pengantar Ilmu Ekonomi, (Dilengkapi Dasar-Dasar Ekonomi Islam), Bandung: Pustaka Setia, 2014.

Ghofur, Abdul. Pengantar Ekonomi Syariah, Jakarta: PT Raja Grafindo, 2017.

Gilarso, T. Pengantar Ilmu Ekonomi Bagian Makro, Yogyakarta: Kanisus, 2004, Cet. ke-2.

Hakim, L, "Distorsi Pasar Dalam Pandangan Ekonomi Islam”, Jurnal Ekomadania, vol. 1, No. 1 (2017).

Hakim, M. Arif. "Peran Pemerintah Dalam Mengawasi Mekanisme Pasar Dalam Perspektif Islam”, IQTISHADIA, Vol. 8, No. 1 (2015).

Huda, Nurul dan Ahmad, Kuangan Publik Isalam pendekatan Al-Kharaj Imam Abu Yusuf, Bogor: Ghalia Indonesia, 2011.

Iklromi, Zuli. "Maslahah dalam Al-Qur'an", AnNur, Vol. 4, No. 2 (2015).

Karim, Adiwarman. Ekonomi Mikro Islam. Jakarta: PT Raja Grafindo Persada, 2015.

Kuswanto, Andi. Pengantar Ekonomi, Depok: Gunadarma, 2013.

Lubis, Suhrawardi K. Hukum Ekonomi Islam, Jakarta: Sinar Grafika, 2000, Edisi 1, Cet. 2.

Marthon, Said. Ekonomi Islam Ditengah Krisis Global, Terjemahan Ahmad Ikhrom, Jakarta: Zikrum Hakim, 2014, Cet. Ke-1. 
Martina, Telopa N. "Pemikiran Ekonomi Abu Yusuf dalam Kitab Al-Kharaj", Jurnal ALINTAJ, vol. 3 (01), Maret 2017

Munif A, Nasrullah, "Critical Anlyisis of Abu Yusuf Thought:the role of Goverment in Islamic Ecomomic”.Jurnal Eksayr, Vol 7 (01), 2019.

Muhajiddin, Ahmad. Ekonomi Islam, Jakarta: PT. Raja Grafindo Persada, 2007.

Mujahidin. Muhammad, Konsep-Konsep Istishlah dan Maslaht Al-Ammah, dikutip dari http:// mujahidinmeis.wordpress.com/tag/ististishlah-dan-maslahat-al-ammah, pada hari rabu 3 agusutus 2020 jam 14:00

Naf'an. Ekonomi MakroTinjauan Ekonomi Syariah, Samarinda: Graha Ilmu, 2014.

Parakkasi, Idris, Kamiruddin. "Analisis Harga Dan Mekanisme Pasar Dalam Perspektif Islam”, LAA MAISYIR Jurnal Ekonomi Islam, Vol. 5, No. 1 (2018).

Pusat Pengkajian dan Penembangan Ekonomi Islam (P3EI), Ekonomi Islam, Jakarta: Rajawali perss, 2009.
Said, Sa'ad Marthoon Ekonomi Islam Ditengah Krisis Global, Terjemahan Ahmad Ikhrom, Jakarta: Zikrum Hakim, 2004, Cet. Ke-1

Sholihin, Ahmas Ifham. Buku Pintar Ekonomi Syariah, Jakarta: Gramedia Pustaka Utama, 2014.

Sopiandi, E. Hafiduddin, D. \& Tanjung, H. Analisis Distorsi Pasar dalam Perspektif Ekonomi Islam, Journal Of Islamic Economy, Vol. 10 (01), 2017.

Sadono, Sukirno. Pengantar Teori Mikroekonomi, Edisi III Cet. XX; Jakarta: PT. Raja Grafindo Persada, 2004.

Suprehaten, "Pemikiran Abu Yusuf Tentang Pasar Dalam Kitab Al-Kharaj", Tesis Universitas Islam Negeri Sultan Syarif Kasim, Riau, 2010.

Syarifudin, Amir. Ushul Fiqih, Jakarta: Prenadamedia, 2014.

Yusuf, Abu. Al-Kharaj, Beirut: Darul Ma’rifat, 1979.

Zulkarnain, Alang, Agung. "Mekanisme Pasar dalam Perspektif Ekonomi Islam”, Jurnal Of Institution and Sharia Finance, Vol. (2) 2018. 